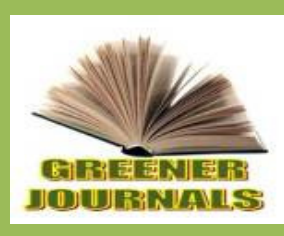

\title{
Aflatoxin Contamination of Stored Groundnut Kernel in Sokoto State, Nigeria
}

\section{*1Salau IA, ${ }^{2}$ Shehu K, ${ }^{2}$ Muhammad S and ${ }^{3}$ Umar RA}

\author{
${ }^{* 1}$ Department of Biology, Shehu Shagari College of Education, Sokoto Nigeria. \\ ${ }^{2}$ Department of Biological Sciences, Usmanu Danfodiyo University, Sokoto Nigeria. \\ ${ }^{3}$ Department of Biochemistry, Usmanu Danfodiyo University, Sokoto Nigeria.
}

Article No.: 092316144

DOI: 10.15580/GJAS.2016.10.092316144

Submitted: 23/09/2016

Accepted: 05/10/2016

Published: 10/11/2016

${ }^{*}$ Corresponding Author

Salau IA

E-mail: ibrahimasalau @gmail

.com

Phone: $+234(0) 8053569551$

Keywords:

Aflatoxin, Contamination, Store

Groundnut kernel and Agricultural

zones
Aflatoxins (AF) are a group of fungal toxins that contaminate foods and feeds with adverse health impact on human beings and animals. A total of sixty three (63) samples of Groundnut kernels from three (3) Agricultural zones of Sokoto State, were analysed for the presence of Aflatoxins B1 $\left(\mathrm{AFB}_{1}\right), \mathrm{B} 2\left(\mathrm{AFB}_{2}\right), \mathrm{G} 1$ $\left(A F G_{1}\right)$ and $G_{2}\left(A F G_{2}\right)$ using High Performance Liquid Chromatography (HPLC). The Aflatoxin was detected in $\mathbf{8 2 . 5 \%}$, the total Aflatoxin concentration ranged between $0.9-646.0 \mu \mathrm{g} / \mathrm{kg}$. All four types of AF were detected from all samples, out of the total samples analysed $38.10 \%$ contained AF levels above the Nigerian (20 $\mu \mathrm{g} / \mathrm{kg}$ ) limits for AF, while $66.7 \%$ samples had AF concentrations above the European Union maximum tolerance level of $2 \mu \mathrm{g} / \mathrm{kg}$ for $A F B_{1}$ and Total Aflatoxin(Tot AF) of $4 \mu \mathrm{g} / \mathrm{kg}$. The result shows that, there were significant $(P>$ 0.05 ) differences between the samples analysed in the state, as regards to AFB ${ }_{1}$. The results also revealed that Groundnut kernel in the study area have high frequency of contamination (82.5\%). However, awareness on danger of Aflatoxin contamination by all stakeholders is the key in effective management of the problem.Relevant quality control units must be reactivated to assess the quality of the Groundnut kernels from which other products are made. 


\section{INTRODUCTION}

Mycotoxins are secondary metabolites present in agricultural products worldwide that are produced by filamentous fungi on invasion of the host tissue and are capable of causing mycotoxicoses on ingestion by human or animals (Glenn, 2007). Mycotoxins are small and quite stable molecules which are extremely difficult to remove or eradicate and maintain their toxic properties along the tropic level in a food chain (Domsch, 2007). Approximately 400 secondary metabolites with toxigenic potential are produced by over 100 moulds. Identified mycotoxin according to Glenn (2007) includes Aflatoxins, fumonisins, ochratoxin, trichothecenes, zearalenone, penitrems and ergot alkaloids.

Aflatoxins (AF) are one of many natural occurring mycotoxins that are found in soils, foods, humans, and animals. Derived from the fungus, the toxigenic strains of Aflatoxins are among the most harmful mycotoxins. Aflatoxins are found in the soil as well as in grains, nuts, dairy products, tea, spices and cocoa, as well as animal and fish feeds (Waliyar et al. 2005). There are six forms of Aflatoxin: Aflatoxin $B 1$ $\left(\mathrm{AFB}_{1}\right)$, Aflatoxin B2 $\left(\mathrm{AFB}_{2}\right)$, Aflatoxin $\mathrm{G} 1\left(\mathrm{AFG}_{1}\right)$, and Aflatoxin G2 $\left(A F G_{2}\right)$ are found in plant-based food, while Aflatoxin $\mathrm{M} 1\left(\mathrm{AFM}_{1}\right)$ (metabolite of $\mathrm{AFB}_{1}$ ) and Aflatoxin M2 $\left(\mathrm{AFM}_{2}\right)$ are found in foods of animal origin. B1 is the most harmful form due to its direct link to human liver cancer (Leslie et al., 2006). The Aflatoxin problem has been recognized as one of the biggest challenges to food and nutrition security, trade, and health across the African continent. Aflatoxins are highly carcinogenic toxins that are produced by strains of the fungi Aspergillus flavus and $A$. parasiticus. In most West African countries, Groundnut, an important crop used in various forms including as a basic food and a cash crop, and which is one of the most susceptible crops to Aflatoxin, has been the worst hit. Since 1960, Groundnut production and exports from the West African region have been declining mostly due to Aflatoxin contamination of Groundnuts and Groundnut products. Small holder farmers are most affected, because they are highly dependent on the Groundnut production as it generates $60 \%$ of rural cash incomes in a number of countries in the region (Akano and Atanda 1990).

Groundnut (Arachis hypogaea) is an economically important crop grown in many parts of the world. Nigeria produced a total of 2.96 million metric tons from approximately 2.3 million hectares in 2011 making it the third largest producer in the world after China and India, the first and second producers, respectively (FAOSTAT 2013). Groundnut is used as human food and animal feed. It is also used for oil production and for many other purposes, and these underscore its importance to the agricultural sector (Bankole et al. 2005).

A major constraint to Groundnut production and trade is the susceptibility of the crop to fungal invasion especially by aflatoxigenic fungi which subsequently produce Aflatoxin in the kernels (Mutegi et al. 2009; Soleret al. 2010). The affected kernels thus lose their quality and market value due to Aflatoxin contaminations. As stated earlier, areas of concern for Groundnuts revolve primarily around contamination by Aflatoxin, a class of mycotoxins produced mainly by Aspergillus flavus and A. parasiticus, in addition to cross-contamination from sources that introduce pathogens to Groundnuts after processing (Chang et al. 2013) In Nigeria, Groundnut is traditionally consumed in its boiled, roasted or other processed form to improve its aroma, flavour and texture, and also destroys contaminating microorganisms.

Nigeria has experienced high recorded Aflatoxin exposure levels in humans and has also reported the highest estimated number of cases of hepatocellular carcinoma (HCC-liver cancer) attributable to Aflatoxin (Liu and $\mathrm{Wu}, 2010$ ) in the whole world. In recent years and in Nigeria, there have been growing concerns over the health hazard on consumption of Agricultural products contaminated with mycotoxin (Aflatoxin in particular) with deleterious consequences to human health. Poor system of farming, processing and storage facilities are factors that lead to the contamination of such products by Aflatoxin producing fungi (WHO, 2013)

The death of some children who consumed mouldy Groundnut cake in Ibadan was suspected to be due to aflatoxicosis (Ikeorah and Okoye 2005).

Aflatoxin determination and identification remain a priority before establishment of any health implication and control system. There are no reports on the incidence of Aflatoxin in Groundnut in Sokoto State which is one of the major Groundnut producing states in the country. For Nigeria to improve its competitiveness in Groundnut trade, the nation must generate data on the occurrence of Aflatoxin in the crop so as to establish whether the levels are safe for human and animal consumption and to further adopt measures to control their contamination levels.

The aim of this research work is to evaluate the presence, incidence, frequency and levels of Aflatoxin contamination of Stored Groundnut kernel in Sokoto State, Nigeria.

\section{MATERIALS AND METHODS}

\section{Study Area}

The study was conducted in Sokoto State, which is located in the extreme North-western part of Nigeria. The State geographically lies along longitude $11^{0} 30^{1}$ to $13^{0} 50^{1}$ East and latitudes $4^{\circ}$ to $6^{1}$ North and covers a total land mass of 26,648.48 square kilometres. Sokoto State shares boundary with Kebbi State to the south, Zamfara State to the east and the Republic of Niger to the north. The State has an estimated population of about $4,742,459$ people as of 2016 with 99.9 persons per square kilometre, and 3\% growth rate annually based on 2006 population census (NPC, 2007). Occupation of city inhabitants includes farming, trading, commerce, with a reasonable proportion of the population working in private and public sectors (MOI, 2008). The soil is predominantly a ferruginous tropical 
type, texturally sandy and $\mathrm{pH}$ of the soil ranges between 6 and 7. Rainfall starts late in June and ends early, in September but, sometimes extend to October. The average annual rainfall is between $550-1300 \mathrm{~mm}$ with peak in the month of August and a relative humidity of less than $20 \%$. The highest temperatures of $45^{\circ} \mathrm{C}$ during the hot season are experienced in the months of March and April. Harmattan, (a dry cold and dusty) condition is experienced between the months of November and February (Abdullahi et al., 2009). Modern Sokoto city is a major commercial centre in leather crafts and agricultural products (MOI, 2008). There are 23 local government councils (LGC) in the State with Sokoto as the capital. The state is divided into four (4) agricultural zones viz Sokoto, Gwadabawa, Isa and Tambuwal.

\section{Sampling}

The State has four agricultural zones namely: Gwadabawa (Sokoto West), Isa (Sokoto East), Sokoto (Sokoto) and Tambuwal (Sokoto South). Each zone has between 5 - 6 local governments' areas (Junaidu, 2005). For the purpose of this study, three (3) zones were randomly selected by balloting; Isa, Sokoto and Tambuwal. Simple random sampling technique was used for sampling of Groundnut kernel in the zones.

\section{Selection of stores}

Stores from selected local government areas were identified through local government departments' of agriculture and traditional authorities.

\section{Determination of Representative Sample Size}

Research work in this area of study is scanty, as such this research work will served as a basis for the estimation of the representative sample size and it will be calculated using the formula below:

$$
\underset{L^{2}}{S}=\underline{x^{2} P Q}
$$

$S=$ Number of stores

$X=$ the $x$ score for a given confidence interval

$\mathrm{P}=$ Estimated prevalence

$Q=1-p$

$\mathrm{L}=$ allowable error of estimation

In this research the desired confidence interval is $95 \%$ with an allowable error of estimation 0.05 the estimated prevalence that will be considered as $47 \%$ (Ezekiel and Sombie, 2014).

\section{Collection of samples}

A total of sixty three (63) stored groundnut samples were collected. Twenty one (21) samples each were collected from each Agricultural Zone. The samples were collected in sterile sampling bags at different storage centres. The samples were store at $0^{\circ} \mathrm{C}$ and immediately transported to the laboratory for Aflatoxin evaluation.

\section{Determination of Samples Moisture}

The moisture content of the samples was determined by rapid moisture analyser instrument (Gaucher model 600) supplied from Witeg, Germany. Weighed samples (250 gm) inserted into the instrument and the percentage moisture content from the digital reader was recorded as the average moisture content of each samples.

\section{Analysis of Aflatoxin}

The samples were subjected to extraction of toxins, clean up and analyzed for B1, G1 B2 and G2 according to the method described by Ehrlich and Lee (1984) without modification. Methylene chloride and phosphoric acid were used for the simultaneous extraction of AFB1, AFB2, AFG1 and AFG2. A separate portion of the initial methylene chloride/phosphoric acid extract was subjected to a specific clean-up procedure for Aflatoxin.

\section{Extraction of Aflatoxin}

Approximately $50 \mathrm{~g}$ portion of pulverized Groundnut kernel sample was weighed into a $500 \mathrm{ml}$ Erlenmeyer flask and $25 \mathrm{ml} 1 \mathrm{M}$ of the phosphoric acid and $250 \mathrm{ml}$ of methylene chloride were added. The flask was placed on a mechanical shaker for 30 minutes and the content filtered under pressure on Buchner funnel fitted through an $18 \mathrm{~cm}$ circle rapid filter paper. Two hundred milliliter of the filtrate was collected and $50 \mathrm{ml}$ aliquot was taken from the filtrate and placed in separate $100 \mathrm{ml}$ Erlenmeyer flasks with glass stoppers, for Aflatoxin assay.

\section{Aflatoxin Clean-up}

The fraction for AFs analysis was subjected to a specific column chromatographic clean-up method. A column was set up with a glass wool and $150 \mathrm{ml}$ of Dichloromethane (DCM) was poured into the column and emptied half way. Anhydrous sodium sulphate $\left(\mathrm{Na}_{2} \mathrm{SO}_{4}\right)$ was added and the sides of the column were washed with DCM. Silica gel was added to the green line of column together with $80 \mathrm{ml}$ of DCM and this was allowed to settle half way. Three scoops of anhydrous sodium sulphate $\left(\mathrm{Na}_{2} \mathrm{SO}_{4}\right)$ were added and the DCM drained off to the top of the packed section of the column. About $50 \mathrm{ml}$ of the filtrate was added and drained off to the top of the packed part of the column. The filtrate was defatted with $130 \mathrm{ml}$ of $\mathrm{N}$-hexane and $130 \mathrm{ml}$ of ether sequentially, and each fraction drained out completely. Aflatoxins were extracted into $130 \mathrm{ml}$ of ether/methanol/water $(96: 3: 1, \mathrm{v} / \mathrm{v} / \mathrm{v})$ that was collected off column in a new beaker. The extract was evaporated to near dryness, put into sealed amber glass vials and stored at $0^{\circ} \mathrm{C}$ for a week until further analysis. 


\section{High Pressure Liquid Chromatography (HPLC)}

Aflatoxins were analyzed on a Cecil 1100 series HPLC system equipped with a UV detector set at a wavelength of $365 \mathrm{~nm}$ as described by Cora et al. (2005). The Altraspher ODS column, $4.6 \mathrm{~mm}$ x 250 $\mathrm{mm}$ was used at ambient temperature of $25^{\circ} \mathrm{C}$. Acetonitrile/ water/acetic acid (10:50:40, v/v/v) were used as the mobile phase pumped at a flow rate of 0.8 $\mathrm{mL} / \mathrm{min}$. The injection volume of both samples and standards used was $20 \mu \mathrm{L}$.

\section{Aflatoxin Standard}

The analysis was carried out with Aflatoxins standards (Sigma Chemical Company, St. Louis, MO, USA) of known concentrations. $\mathrm{AFB}_{1}, \mathrm{AFG}_{1}$ and $\mathrm{AFB}, \mathrm{AFG} \mathrm{F}_{2}$ eluted at distinct retention times of $1.673 \mathrm{~min}$ and $1.524 \mathrm{~min}$ respectively. Calibration curves with correlation coefficient $\left(R_{2}\right)$ of 0.91 and 0.99 were established for $\mathrm{AFB}_{1}, \mathrm{AFG} \mathrm{G}_{1}$

and $A F B_{2}, A F G_{2}$ using a series of dilutions containing $(0.004,0.008,0.012$ and $0.016 \mu \mathrm{g} / \mathrm{ml})$ and $(0.01,0.02$, 0.03 and $0.04 \mu \mathrm{g} / \mathrm{ml}$ ) respectively for each standard. The limits of detection (LOD) were estimated as follows: known concentrations of Aflatoxin standards were prepared, successively diluted and subjected to HPLC until the minimum concentration at which the analyte could be detected was established. The LOD of the HPLC instrument with regards to both toxins was determined to be 0.21 and $0.18 \mu \mathrm{g} / \mathrm{kg}$ while the limits of quantification (LOQ) were estimated based on the standard deviations of response and slope; this gave 0.42 and $0.33 \mu \mathrm{g} / \mathrm{kg}$ respectively.

Quantification of the actual Aflatoxin in $\mu \mathrm{g} / \mathrm{kg}$ is based on the following formula:

$$
\text { Mycotoxin content }(\mu \mathrm{g} / \mathrm{kg})=\frac{\mathrm{S} \times Y \times V}{W \times Z}
$$

Where:

$\mathrm{S}=$ volume of standard with same colour intensity as sample ( $\mu \mathrm{l})$;

$\mathrm{Y}=$ concentration of mycotoxin standard used in $\mu \mathrm{g} / \mathrm{ml}$;

$\mathrm{V}=$ volume of solvent required to dilute sample contained in final extract;

$\mathrm{W}=$ effective weight $(\mathrm{g})$ of original sample contained in final extract;

$Z$ = volume of spotted sample equivalent to standard $(\mu \mathrm{L})$.

\section{Data analysis}

The SPSS 21.0 (Windows version, IL, USA) was used for data analysis. Means for the distribution of concentrations of Aflatoxin were calculated and tested for significance at $95 \%$ confidence level by one-way ANOVA. The Duncan's multiple range tests was further used to separate the means.

\section{RESULT}

\section{Moisture content of Stored Groundnut kernel}

The percentage moisture contents of Groundnut Kernel in relation to samples collected from different zones is shown in Fig 1. The results showed that the samples collected from Tambuwal zone had the highest moisture contents (13.5\%), followed by Sokoto $(10 \%)$ while samples from Isa zone had the lowest moisture content $(8 \%)$.

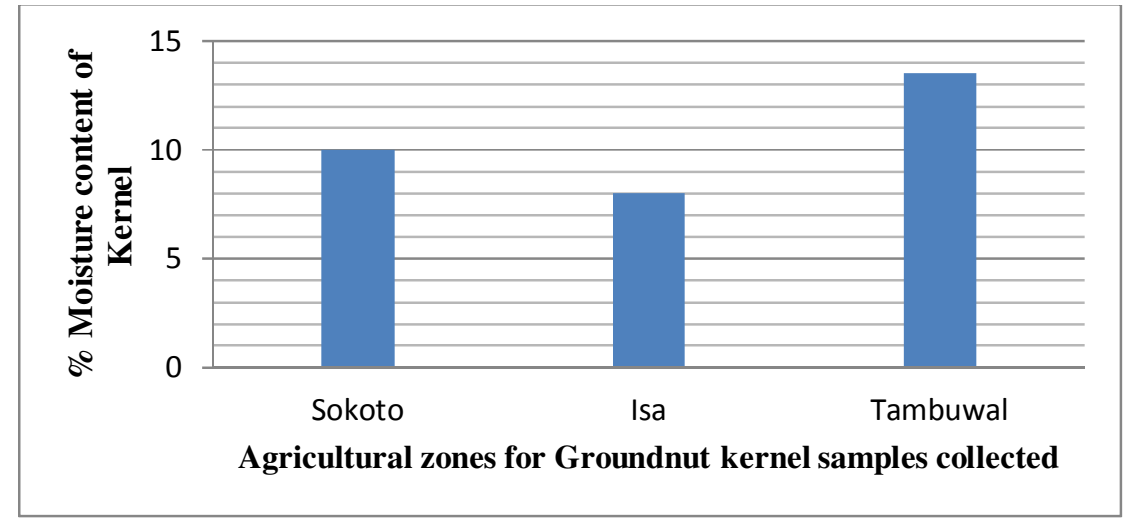

Fig. 1: Groundnut Kernel Mean moisture content (\%) in samples collected from different zones

\section{Aflatoxin contamination of Groundnut kernels}

The levels of Aflatoxin in Groundnut kernel obtained in Sokoto are presented in Table 1. Sixteen samples out of twenty one (76.2\%) in Sokoto zone were contaminated with the Aflatoxin. The highest levels of Aflatoxin were $\mathrm{AFB}_{1}(1.0-221.0 \mu \mathrm{g} / \mathrm{kg})$, followed by $A F G_{1}$ and $A_{F B}(1.5-113.0$ and $1.1-76.0 \mu \mathrm{g} / \mathrm{kg})$ respectively, the lowest concentrations of Aflatoxin were recorded for $A F G_{2}(1.8-22.0 \mu \mathrm{g} / \mathrm{kg})$. In the Isa zone of Sokoto state, eighteen samples out of twenty one $(85.7 \%)$ were found to be contaminated with the Aflatoxin. The results indicated that the highest levels of Aflatoxin were $\mathrm{AFB}_{1}(1.3-156.0$ $\mu \mathrm{g} / \mathrm{kg}$ ), followed by $A F B_{2}$ and $A F G_{1}(0.2-88.0$ and 0.5 - $61.0 \mu \mathrm{g} / \mathrm{kg}$ ) respectively, the lowest Aflatoxin 
concentrations were recorded for $\mathrm{AFG}_{2}(0.5$ - 12.0 $\mu \mathrm{g} / \mathrm{kg}$ ). In Tambuwal zone, eighteen sample out of twenty one $(85.7 \%)$ were contaminated with the Aflatoxin. The results reveal that the highest levels of Aflatoxin were $\mathrm{AFB}_{1}(0.9-450.5 \mu \mathrm{g} / \mathrm{kg})$. This levels represent the highest range of concentration found in all the remaining sampling zones in the state, while the moderate levels were found on $\mathrm{AFB}_{2}$ and $A F G_{1}(0.1$ 101.0 and $1.0-96.8 \mu \mathrm{g} / \mathrm{kg}$ ) respectively, the lowest Aflatoxin concentrations were recorded for $\mathrm{AFG}_{2}(1.1$. $28.0 \mu \mathrm{g} / \mathrm{kg}$ ).

All the contaminated Groundnut kerne samples were found to contain $\mathrm{AFB}_{1}$ at concentrations ranging from 0.9 and $450.0 \mu \mathrm{g} / \mathrm{kg}$. The least and highest concentrations of $\mathrm{AFB}_{1}$ were detected in samples obtained from Tambuwal (Table 2). However, the mean $\mathrm{AFB}_{1}$ concentration in samples analysed by locations were significantly $(p>0.05)$ different from each other. Out of 63 samples, more than thirty eight $(38.1 \%)$ were contaminated with $>20 \mu \mathrm{g} / \mathrm{kg}$ AFB1 [maximum acceptable limit (MAL) recommended by the National Agency for Food and Drug Administration and Control (NAFDAC). $\mathrm{AFB}_{1}$ and total Aflatoxin $\left(\Sigma A F B_{1}, A F B_{2}, A F G_{1}\right.$ and $\left.A F G_{2}\right)$ in the Groundnut samples from three Agricultural zones of Sokoto States Nigerian were presented in Table 4. Aflatoxin $\mathrm{B}_{1}$ and total Aflatoxin levels were significantly $(\mathrm{P}<$ 0.05 ) different (means $=47.91$ and $84.28 \mu \mathrm{g} / \mathrm{kg}$, respectively) and Groundnut from Tambuwal (means = 55.41 and $92.87 \mu \mathrm{g} / \mathrm{kg}$, respectively) and those collected from Isa (means = 39.96 and $64.00 \mu \mathrm{g} / \mathrm{kg}$, respectively) and Sokoto (means $=48.36$ and 95.96 $\mu \mathrm{g} / \mathrm{kg}$, respectively). Overall, $52(82.5 \%)$ of the 63 samples were contaminated with Aflatoxins: $\mathrm{AFB}_{1}$ (range $=0.9-450.0 \mu \mathrm{g} / \mathrm{kg} ;$ mean $=47.91 \mu \mathrm{g} / \mathrm{kg}$ ) and total Aflatoxin (range $=0.9-646.0 \mu \mathrm{g} / \mathrm{kg}$; mean $=84.28$ $\mu \mathrm{g} / \mathrm{kg}$ ). The $\mathrm{AFB}_{1}$ maximum limit of $20 \mathrm{ng} / \mathrm{g}$ in Nigerian foods adopted by the National Agency for Food and Drug Administration and Control (FAO 2004) was exceeded in 24 (38.10\%) of the Groundnut samples, while $42(66.7 \%)$ of the samples had AFB1 and total Aflatoxin levels above the stipulated EU limit of 2 and 4 $\mu \mathrm{g} / \mathrm{kg}$, respectively (FAO 2004) (Table 2). 


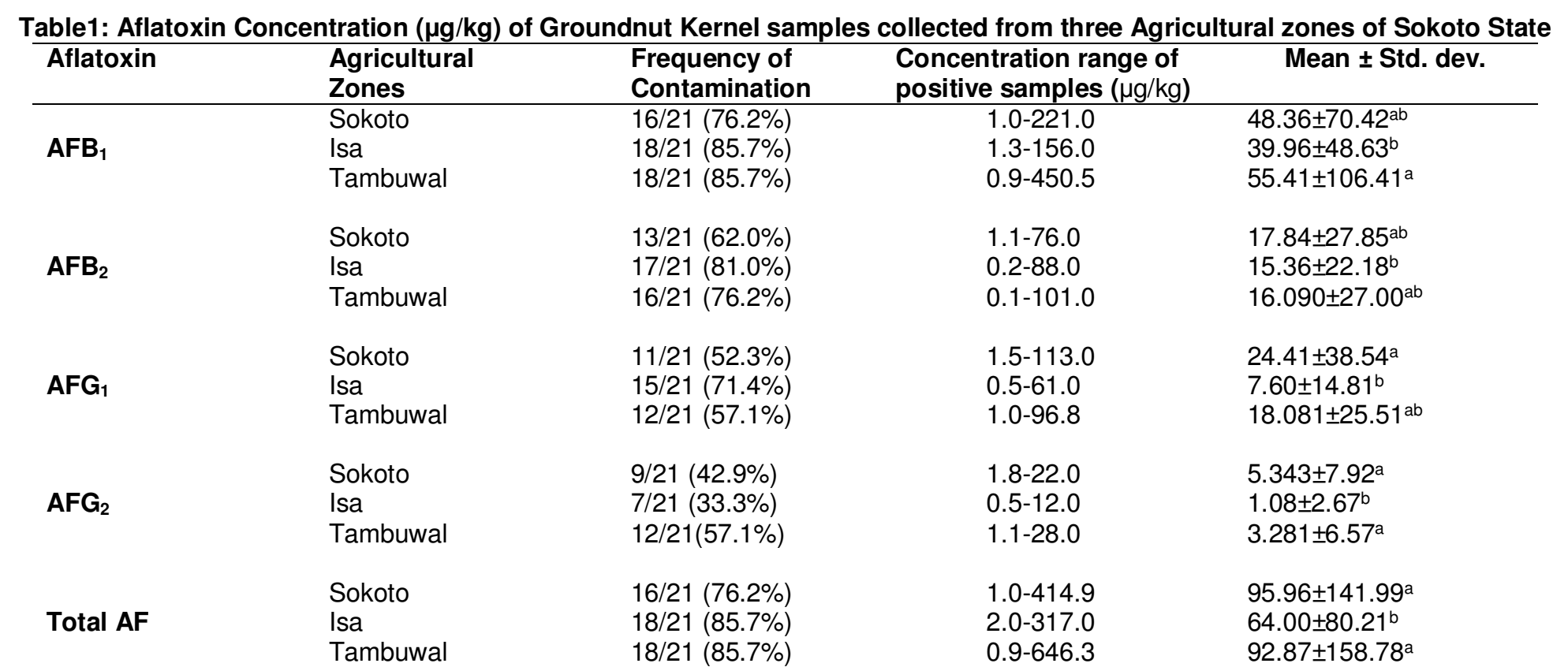

Means followed by the same letter(s) do not differ significantly according to Duncan Multiple Range Test (DMRT) at $5 \%$ level of significance.

Table 2:Incidence of Aflatoxin Concentrations in Groundnut Kernels from Three Agricultural Zones in Sokoto States, Nigeria

\begin{tabular}{|c|c|c|c|c|c|c|c|c|}
\hline \multirow[b]{2}{*}{ Sampling location } & \multirow[b]{2}{*}{ N (\%) } & \multicolumn{4}{|c|}{ AflatoxinB $B_{1}$ concentration $(\mu \mathrm{g} / \mathrm{kg})$} & \multicolumn{3}{|c|}{ Total Aflatoxin concentration $(\mu \mathrm{g} / \mathrm{kg})$} \\
\hline & & Range & Mean & $\mathbf{N}(\%)>2$ & $\mathbf{N}(\%)>20$ & Range & Mean & $\mathrm{N}(\%)>4$ \\
\hline Sokoto & 16/21 (76.2) & $1.0-211.0$ & $48.36^{a b}$ & 13/21(62.0) & $8 / 21(38.10)$ & $1.0-414.9$ & $95.96^{a}$ & 13/21 (62.0) \\
\hline Isa & $18 / 21(85.7)$ & $1.3-156.0$ & $39.96^{b}$ & $14 / 21(66.7)$ & $8 / 21(38.10)$ & $2.0-317.0$ & $64.00^{b}$ & $15 / 21(71.4)$ \\
\hline Tambuwal & 18/21 (85.7) & $0.9-450.5$ & $55.41^{a}$ & $15 / 21(71.4)$ & $8 / 21(38.10)$ & $0.9-646.3$ & $92.87^{a}$ & $14 / 21(66.7)$ \\
\hline Total & $52 / 63(82.5)$ & $0.9-450.0$ & 47.91 & $42 / 63$ (66.7) & $24 / 63(38.10)$ & $0.9-646.3$ & 84.28 & $42 / 63(66.7)$ \\
\hline
\end{tabular}

Means followed by the same letter(s) do not differ significantly according to Duncan Multiple Range Test (DMRT) at $5 \%$ level of significance

$\mathbf{N}=$ Number of samples contaminated with Aflatoxins.

$>\mathbf{2}$ and $>\mathbf{4}=$ Maximum limit for Aflatoxin $\mathrm{B}_{1}$ and Total Aflatoxin concentrations, respectively (EU)

$>\mathbf{2 0}=$ Maximum limit for Aflatoxin B1 concentration in foods (NAFDAC) 


\section{DISCUSSION}

\section{Moisture Content of Groundnut kernel}

The moisture content observed in Groundnut kernel from this study indicates that $8 \%$ moisture was encountered in all the zones studied. This was conductive to encourage the growth of fungi in Groundnut (Woodroof 1984). Recent report of Halima (2000) also supports the view that fungi can grow on variety of situations and thrives under conditions of moisture, warmth and good supply of organic food which subsequently produce Aflatoxin. Contamination in stored groundnut is dependent on the moisture content of the harvested groundnut prior to storage. Therefore groundnuts which are stored before sale or use should be kept dry with a maximum moisture content of not more than $7 \%$ and $13 \%$ for EU and SON respectively. The moisture content obtained from groundnut cake was found to be within the range as reported by Atanda (1990).

\section{Aflatoxin contamination of Groundnut kernels}

This study analysed 63 samples for the presence of Aflatoxins in stored Groundnut kernels and was determine to be $82 \%$ contamination with Aflatoxins in a concentrations range between $0.90 \mu \mathrm{g} / \mathrm{kg}$ to $646.00 \mu \mathrm{g} / \mathrm{kg}$. Four types of Aflatoxin $\left(\mathrm{AFB}_{1}, \mathrm{AFB}_{2}\right.$ $A F G_{1}$ and $A F G_{2}$ ) were detected. Of the Aflatoxins detected, $A F B_{1}$ had the higher frequency $(82.5 \%)$ of occurrence. Similarly, Patrick et al. (2009) found AFB and $A F G_{1}$ as the most frequently occurring types of Aflatoxin in stored Groundnut samples. The Aflatoxin levels found in the Groundnut samples were much lower in value than those earlier reported in Groundnut by Afolabi et al., 2014, Kayode et al., 2013 and roasted Groundnut by Ogunsanwo et al. (2004) and Bankole et al. (2005). It's also similar to the levels found in study carried out by Akano and Atanda 1990 and Ezekiel et al., 2013 in Lagos, Nigeria. And much higher than that by Odoemelam and Osu 2009, who investigated Aflatoxin B1 contamination of some food grains marketed in Nigeria. The result of this study is against the view of Afolabi et al., 2014, who considered Groundnut contamination in south western part of Nigeria may have been due to the soil types, time lag, post harvest handling and storage conditions during transportation of kernels from Groundnut producing regions (Northern Nigeria) to the South-Western zones where it is largely consumed. It is well known that the environmental factors (temperature, relative humidity and amount of rainfall) in south west is per greater than that northern Nigeria, and the can influence the production of Aflatoxin during storage, transportation and processing.

In two different studies conducted in Nigeria, McDonald (1964) reported that Groundnuts cultivated in the northern parts of Nigeria were contaminated with Aflatoxin levels up to $2000 \mu \mathrm{g} / \mathrm{kg}$, while Akano and Atanda 1990 reported Aflatoxin B1 levels of between $37-455 \mu \mathrm{g} k$ in Groundnut purchased from markets in Ibadan, Oyo State Nigeria. Adebajo and Idowu (1994) reported that most of the corn-Groundnut snack ('donkwa') contained Aflatoxins above $30 \mu \mathrm{g} / \mathrm{kg}$ immediately after preparation. In some part of the world Park and Njapau 1989 reported AFB $_{1}$ levels of between $20-200 \mu \mathrm{g} / \mathrm{kg}$ in Groundnut from Senegal and Argentina, while Singh et al., (1982) reported $\mathrm{AFB}_{1}$ levels between $33-440 \mu \mathrm{g} / \mathrm{kg}$ in Groundnut from India and Krishna et al., (2002) reports a levels of between 110-608 $\mu \mathrm{g} / \mathrm{kg}$, in India Yameogo and Kassamba (1999) reported that seeds of Groundnuts from Burkina Faso inoculated with A.flavus excreted all the four major Aflatoxins, which peaked at $170 \mu \mathrm{g} / \mathrm{kg}$ after 6 days. Aflatoxin formation in Groundnut is favoured by prolonged end of season drought and associated elevated temperature (Rachaputi et al., 2002).

Although the levels of $\mathrm{AFB}_{1}(0.9-450.0 \mu \mathrm{g} / \mathrm{kg})$ now being reported for Groundnut is within the range reported elsewhere, differences between these results and that obtained from other researchers may be due to variation in geographical origin, seasonal variation of the samples tested and weather conditions. It seems that difference in harvest and storage conditions as well as the agricultural practices (in each location) also influenced the level of Aflatoxin contamination of the Groundnut. Three environmental factors (temperature, relative humidity and amount of rainfall) influence the production of Aflatoxin in the field and during storage. Studies done on the effect of environmental conditions on Aflatoxin contamination of corn showed that, when the conditions were favourable, the occurrence of Aflatoxin was highly related to these factors (Farombi, 2003). Temperature is an important factor for growth of Aspergillusflavus. In a study on the effect of temperature on Aflatoxin production, Viquez et al., 2006 observed that Aflatoxin level was significantly affected by temperature. The study area has optimal temperature, humidity and light for the growth of Aflatoxigenic moulds. This may be responsible for the detection of Aflatoxin B1 in all the positive samples.

\section{CONCLUSION}

It is concluded that, Aflatoxin contaminated stored groundnut kernel in three Agricultural zones of Sokoto state, contamination in stored Groundnut kernel are dependent on the moisture content of the Groundnut kernel prior to storage. The result of this study revealed that Aflatoxin contamination is more in Isa and Tambuwal stored Groundnut kernel (85.7\% each) than Sokoto $(76.2 \%)$. More than $30 \%$ of Groundnut kernels are at levels greater than MAL of NAFDAC. Therefore Groundnuts which are stored before sale or use should be kept dry with a maximum moisture content of not more than $7 \%$, to prevent contamination by moulds or other microbes from the environment and consequent toxin liberation.

The study recommended that Research has to be done to breed Groundnut varieties that are resistant 
to Aspergillus spp. which subsequently lead to Aflatoxin contamination of kernels and relevant quality control units must be reactivated to assess the quality of the Groundnut kernels from which other products are made.

\section{ACKNOWLEDGEMENT}

The authors are thankful to the laboratory staff of Crop protection Department, Institute of Agricultural Research ABU Zaria and Centre for Biotechnology, FUT Minna for their assistance for the conducts of this research study.

\section{REFERENCES}

Adebajo LO, Idowu, AA.andAdesanya OO (1994). Mycoflora and mycotoxins production in Nigerian corn and corn based snacks. Mycopathologia126:183-192.

Akano DA and Atanda, OO. (1990) The present Level of Aflatoxin in Nigeria Groundnut Cake ('Kulikuli').Letters in App. Microbiol. 10: 187-18.

AOAC International (2008) Official methods of analysis of AOAC International. 18th edition. Gaithersburg, MD, USA, Association of Analytical Communities.

Bankole SA, Ogunsanwo BM and Eseigbe DA. (2005) Aflatoxins in Nigerian dry-roasted Groundnuts Food Chem 89:503-506.

Bankole SA and Mabekoje OO.(2004) Mycoflora and Occurrence of Aflatoxin B1 in Dried Yam Chips from Markets in Ogun and Oyo States, Nigeria.Mycopathologia.157(1):111-115.

Chang AS, Sreedharan A, Schneider KR. (2013) Peanut and peanut products: a food safety perspective. Food Contr 32:296-303.

Cora IB, Angre D, Ronald EM (2005). Separation of aflatoxins by HPLC application. Agilent Technology publication 5989-3634EN www.agilent.com/chem, 16th August, 2006.

Domsch KH, Gams W and Anderson TH (2007). Compendium of Soil Fungi, IHW-Verlag, Eching.

Ehrlich KC, Lee LS (1984). Mycotoxin grain dust: method of analysis of aflatoxin, ochratoxin $A$, Zearalenone, Vomitoxin and secalomic acid. J. Assoc. Official Anal. Chem. 67: 963.

Ezekiel CN, Sombie JI (2014). Survey of aflatoxins and fungi in some commercial breakfast cereals and pastas retailed in Ogun State, Nigeria.Nat Sci ;12(6):27-32

Ezekiel, C. N., Sulyok, M., Babalola, D. A., Warth, B., Ezekiel, B. C. and Krska, R. (2013) Incidence and consumer awareness of toxigenicAspergillus section Flavi and Aflatoxin B1 in Groundnut cake from Nigeria. Food Cont. 30:596-601

FAOSTAT.(2013) Faostat homepage.www.faostat.fao. org/site/339/default.aspx [accessed February 27, 2013].

Farombi EO (2003). African Indigenous plants with chemotherapeutic potentials and biotechnological approach to production of bioactive prophylactic agents. Afr. J. Biotech. 2(12): 662-671.

Food and Agriculture Organization.(2004). Worldwide regulations for mycotoxins in food and feed in (2003).FAO Foodand Nutrition Paper no. 81. Rome: Food and Agriculture Organization, Pp. 1180.

Glenn AE (2007)MycotoxigenicFusariumspecies in animal feed.Anim Feed Sci Technol. 137(3-4): 213-240.

Junaidu AU (2005) Epidemiological Studies on Brucellosis in Sokoto State.PhD Thesis, Dept. of Vet.Public Health and Animal Prod.UsmanuDanfodiyo University, Sokoto.Pp 167

Kayode OF, Sulyok M, Fapohunda SO, Ezekiel NC, Krska R and Oguntona CRB (2013).Mycotoxin and fungal metabolites in groundnut and maize-based snacks from Nigeria,Food Additives and Contaminants; 6:4, 294-300.

Krska R, Welzing E and Boudra $\mathrm{H}$ (2007).Analysis of fusarium toxins in feed, Ani. Feed. Sci. Tech. 137:241-264

Leslie JF, Summerell BA (2006) TheFusariumLaboratory Manual. lowa State University Press, lowa. 400pp

Liu Y, Wu F (2010) Global burden of aflatoxin-induced hepatocellular carcinoma: a risk assessment Environmental Health Perspectives 118:818-824.

McDonald D (1964). Progress reports on research into Aflatoxin production in Groundnuts in Northern Nigeria. Samaru Miscellaneous Papers 2: 13p.

Mutegi CK, Ngugi HK, Hendriks SL, Jones RB. (2009) Prevalence and factors associated with Aflatoxin contamination of Groundnuts from Western Kenya. Int J Food Microbiol 130:27-34.

National Population Commission (NPC, 2007).Population Census Data, Nigeria, Federal Republic of Nigeria Official Gazette, National and State Provisional Total Census, Printed and Published in Federal Government Printer, Lagos, No 21 vol.94,

Odoemelam SA. andOsu Cl (2009). Aflatoxin B1 contamination of some edible grains marketed in Nigeria. E-J. Chem. 6(2): 308-314

Ogunsanwo BM, Faboya OOP, Idowu OR, Lawal OS, Bankole SA. (2004) Effect of roasting on the Aflatoxin contents of Nigerian Groundnut seeds. Afri J Biotechnol 3:451-455.

Rachaputi NR, Wright GC, Kroschi S (2002). Management practices to minimise pre-harvest Aflatoxin contamination in Australian Groundnuts. Austr. J. Exp. Agric. 42: 595-605.

Singh K, Frisvad JC, Thrane U, Mathu SB (1982). An illustrated manual on identification of some seed borne Aspergilli, Fusaria, Penicillia and their mycotoxins. Heller up, Denmark: Danish Government, Institute of seed pathology for developing countries. P. 133.

Soler CMT, HoogenboomOlatinwo R, Diarra B, Waliyar F, Traore S. (2010) Groundnut contamination by Aspergillusflavus and Aflatoxin B1 in granaries of villages and markets of Mali, West Africa. J Food Agric Environ 8:195-203. 
Waliyar F, Reddy SV and Kumar PL (2005) Estimation of Aspergillusflavus infection and Aflatoxin Contamination in Seeds: Laboratory Manual. International Crops Research Institute for the Semi-Arid Tropics, Patancheru 502 324, India. $26 p p$.

Woodroof JG. (1984) Peanuts: Production, Processing, Products, 3rd edn. Westport, CN, TheAvi Publishing Company.

World Health Organization (WHO, 2006) Mycotoxin in African foods: Implications to Food Safety and
Health. AFRO Food Safety Newsletter, World Health Organization Food safety (FOS).

Wu F. (2007). Measuring the economic impacts of Fusarium toxins in animal feeds Anim Feed SciTechnol. 137(3-4): 363-374.

Yameogo RT, Kassamba B (1999). Aspergillusflavusand Aflatoxin on tropical seeds used for snacks Arachis hypogaea, Balanites aegyptiaca and Sclerocaryabirrea. Trop. Sci. 39: 46-49.

Cite this Article: Salau IA, Shehu K, Muhammad S and Umar RA (2016). Aflatoxin Contamination of Stored Groundnut Kernel in Sokoto State, Nigeria. Greener Journal of Agricultural Sciences, 6(10): 285-293, http://doi.org/10.15580/GJAS.2016.10.092316144. 